\title{
Healing of a Tooth with an Overinstrumented Apex, Extensive Transportation and Periapical Lesion Using a 5 mm Calcium Hydroxide Apical Plug: An 8-Year Follow-up Report
}

\author{
Ronaldo Araújo SOUZA ${ }^{1}$ \\ Yara T. Corrêa SILVA-SOUSA ${ }^{1}$ \\ Suely COLOMBO ${ }^{2}$ \\ Maurício $\mathrm{LAGO}^{2}$ \\ Marco Antonio Hungaro DUARTE ${ }^{3}$ \\ Jesus Djalma PÉCORA ${ }^{4}$ \\ ${ }^{1}$ Graduate Department, Dental School, University of Ribeirão Preto, Ribeirão Preto, SP, Brazil \\ ${ }^{2}$ Dental School, Bahiana School of Medicine and Public Health, Salvador, BA, Brazil \\ ${ }^{3}$ Bauru Dental School, USP - University of São Paulo, Bauru, SP, Brazil \\ ${ }^{4}$ Ribeirão Preto Dental School, USP - University of São Paulo, Ribeirão Preto, SP, Brazil
}

\begin{abstract}
Besides the risk of filling material extrusion throughout the apex, a satisfactory apical seal can be difficult to achieve in canals with open apices or iatrogenic enlargements of the apical constriction. These situations pose a challenge to root canal filling. This paper describes the root canal filling of a maxillary right canine with an overinstrumented apex, complete loss of the apical stop, extensive canal transportation and apical periodontitis. A $5 \mathrm{~mm}$ calcium hydroxide apical plug was placed before root canal filling. The plug was made by soaking paper points with saline, dipping the points in calcium hydroxide powder and then applying it to the apex several times, until a consistent apical plug was obtained. The canal was then irrigated with saline in order to remove any residual calcium hydroxide from the root canal walls, dried with paper points and obturated with an inverted \#80 gutta-percha cone and zinc oxideeugenol based sealer by the lateral condensation technique. An 8-year radiographic follow-up showed formation of mineralized tissue sealing the apical foramen, apical remodeling and no signs of apical periodontitis.
\end{abstract}

Key Words: necrotic pulp, open apex, overinstrumentation, apical plug.

\section{INTRODUCTION}

Teeth displaying canals with open apices or iatrogenic enlargements of the apical constriction pose a challenge to endodontic treatment (1) and a satisfactory apical seal can be hard to achieve in these clinical situations. Difficulties are evident during the root canal filling (2). Besides the great risk of filling material extrusion to the periapical tissues, the lack of an apical stop makes the filling in all dimensions virtually impossible (3).

Closing of the apex with a mineralized tissue barrier with long-term calcium hydroxide $(\mathrm{CH})$ use, as in apexification treatment $(4,5)$, has been an alternative for cases of overinstrumented apices. However, this procedure may raise some problems, such as the longer chairside time (2) and the increase of the risk of dental fracture (6). Another factor that could potentially lead to failure during this lengthy process is the risk of contamination between each visit (2).

The implementation of a mineral trioxide aggregate (MTA) apical plug has been proposed for cases of open apex or overinstrumentation (7). However, this material has a high cost and presents difficulties in its application to the apical region, including the risk of extrusion to the periapical tissues, which could cause 
tissue injury and damage to the repair process (8).

The use of $\mathrm{CH}$ to create an apical plug may minimize these problems and also allow an immediate canal filling, making treatment time shorter. $\mathrm{CH}$ does not set, so, if it extrudes to the periapical region, due to its solubility it will be resorbed and will not interfere with the repair.

This paper demonstrates the use of $\mathrm{CH}$ as an apical plug in a maxillary right canine with necrotic pulp, apical periodontitis and enlarged apex with lack of apical stop due to overinstrumentation.

\section{CASE REPORT}

An adult male patient with a maxillary right canine with necrotic pulp, apical periodontitis, and overinstrumentation, with complete loss of the apical stop and extensive canal transportation, was referred to our dental service for root canal filling. The tooth had been instrumented by another professional and, according to the referral, the impossibility of fitting a gutta-percha master cone did not permit root canal filling at that time.

After anesthesia and rubber dam isolation, the root canal was accessed and gently instrumented with a \#80 K-file (Maillefer, Ballaigues, Switzerland) $3 \mathrm{~mm}$ short of the apex. Irrigation was carried out with $3 \mathrm{~mL}$ of $2.5 \%$ sodium hypochlorite $(\mathrm{NaOCl})$, with the irrigation needle positioned $4 \mathrm{~mm}$ short of the apex and then the root canal was dried with paper points.

For smear layer removal, the canal was flooded with $1 \mathrm{~mL}$ of $17 \%$ EDTA (Inodon, Porto Alegre, RS, Brazil), which was stirred with a Lentulo spiral (Maillefer, Ballaigues, Switzerland) and then allowed to remain in the canal for $3 \mathrm{~min}$. Next, the canal was irrigated with $3 \mathrm{~mL}$ of $2.5 \% \mathrm{NaOCl}$, which was also stirred with a Lentulo spiral and remained in the canal for additional $5 \mathrm{~min}$. Finally, the root canal was irrigated with $4 \mathrm{~mL}$ of saline, dried with paper points and dressed with a $\mathrm{CH}$-saline paste applied by a lentulo spiral, for 2 weeks.

At the second visit, after anesthesia and application of the rubber dam, the $\mathrm{CH}$ paste was rinsed from the root canal with $2.5 \% \mathrm{NaOCl}$ and the canal was irrigated with $5 \mathrm{~mL}$ of saline and dried with sterile paper points.

A poor fit of the master cone was observed (Fig. 1A). In order to prevent the extrusion of the root canal filling, a $5 \mathrm{~mm} \mathrm{CH}$ plug was placed at the apical foramen. The plug was created by soaking paper points of compatible diameter with saline, dipping the points in $\mathrm{CH}$ powder and then applying it to the apex. This process was repeated several times, until an apical plug was obtained. The condensation of the apical plug was complemented with a \#80 gutta-percha cone to strengthen it and allow effective condensation of the root canal filling. Then, another \#80 gutta-percha cone was pressed against the apical plug to verify its resistance as a barrier against overfill. The canal was irrigated with $5 \mathrm{~mL}$ of saline in order to remove residual $\mathrm{CH}$ from the walls and dried with sterile paper points.

An inverted \#80 gutta-percha cone was placed and checked (Fig. 1B). Then, the canal was filled with the inverted \#80 gutta-percha cone, accessory cones and Fill Canal sealer (Dermo Laboratório Ltda. Rio de Janeiro, RJ, Brazil), according to the lateral condensation technique (Fig. 1C).

A radiograph taken 85 days after filling revealed absence of the $\mathrm{CH}$ plug and the presence of a large void in the apical portion of the canal (Fig. 1D). An 8-year radiographic follow-up showed apical remodeling, with thickening of the root canal wall, apical closure and no signs of apical periodontitis (Fig. 1E).

\section{DISCUSSION}

The aim of using an apical plug is the placement of a physical barrier at the foramen to prevent extrusion of filling materials during root canal filling in teeth with necrotic pulp and wide-open or overinstrumented apices. After achieving an effective plug, the canal can be sealed. Treatment time is therefore reduced and the risk of contamination is minimized.

Presently, MTA is considered by many authors as the material of choice for apical plug in cases of necrotic pulp (9) and wide-open apices (4,10-12). One of the major reasons is its good sealing ability (5). However, the extrusion of this material to the periapical tissue can interfere with the repair process (8).

$\mathrm{CH}$ is known for its antimicrobial action and ability to stimulate mineralization (13). For these reasons, this material is commonly used in pulpotomies (14) and as an intracanal medication (15). However, $\mathrm{CH}$ could also be used as an apical plug with the goal of creating a barrier to prevent extrusion of root canal filling material during the filling process.

It may be argued that the use of $\mathrm{CH}$ as an apical plug can be questioned due to its poor sealing ability 
and resorption over time, leaving a void at the apical foramen (Fig. 1D), which could decrease the chances of success. The larger the plug, the larger the resulting void after resorption. However, the $\mathrm{CH}$ paste, if kept inside the canal for a long time with a well performed coronal seal, allows the histological repair of lesions and closure of the apical foramen by mineralized tissue (16). This fact demonstrates that although solubilization occurs, it provides apical closure by induction of mineralized tissue deposition, thus promoting the definitive seal of the root canal.
It should be kept in mind that an apical plug is supposed to be a physical barrier and the $\mathrm{CH}$ apical plug fulfills this requirement, as shown in the reported case. Furthermore, the theory that says that presence of voids within the root canal system after root canal filling would lead to failure of the treatment (17) has not been confirmed over time (18-20). The presence of an extensive void after the resorption of the $\mathrm{CH}$ apical plug (Fig. 1D) did not prevent the repair and apical seal, as occurred in this case (Fig. 1E).

The lack of radiopacity of $\mathrm{CH}$ could be considered
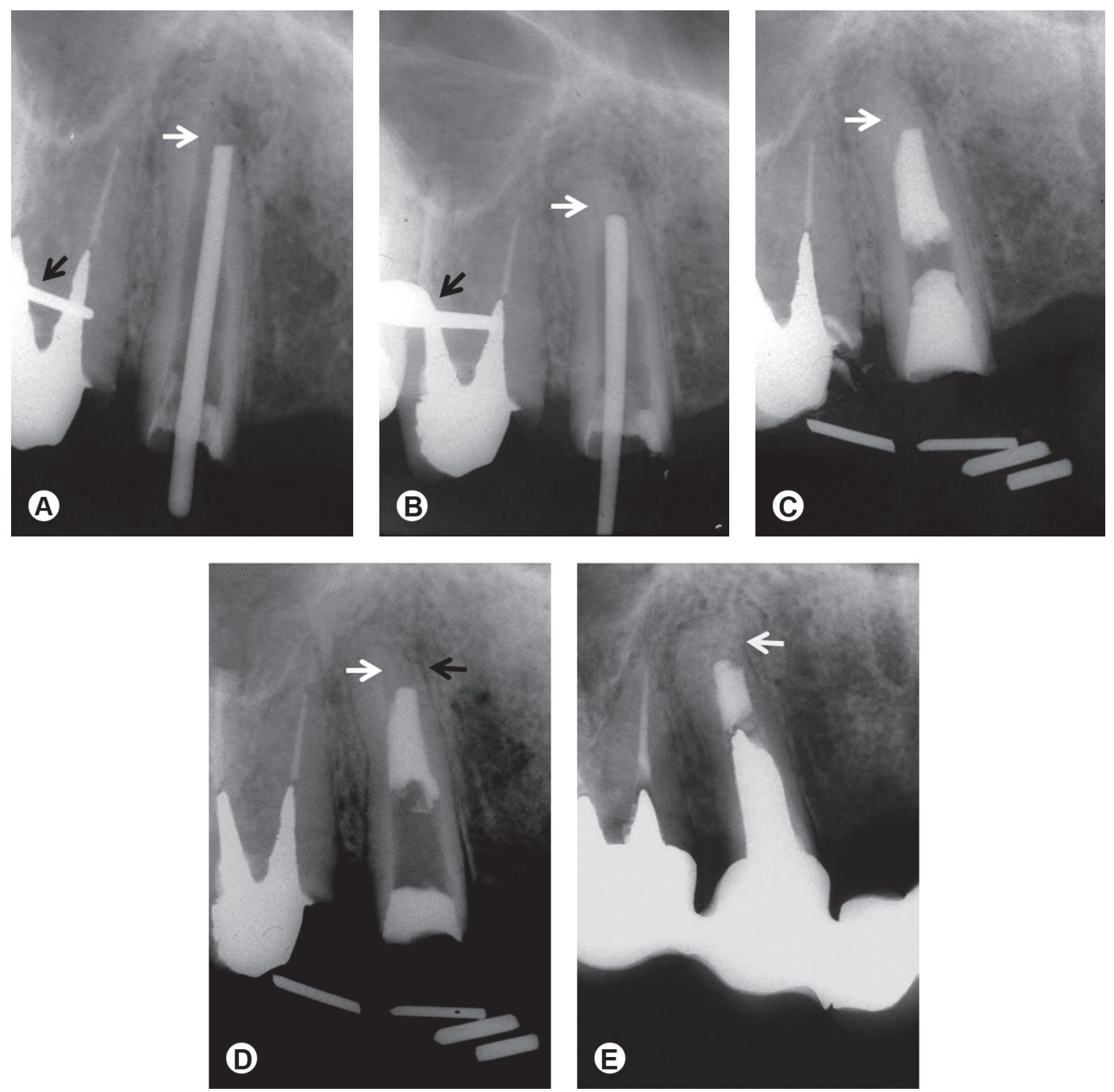

Figure 1. Overinstrumented apex. A: Radiographic image showing a periapical lesion, overinstrumented apex and poor fit of the master cone (white arrow). Observe the wing of the rubber dam clamp (black arrow). B: Calcium hydroxide apical plug and fit of the inverted \#80 gutta-percha cone (white arrow). Wing of the rubber dam clamp can be seen (black arrow). C: Immediate postoperative radiograph with calcium hydroxide apical plug (arrow) and root canal filling. D: Note the extensive void left after resorption of the calcium hydroxide plug (white arrow) and a very thin wall of the root (black arrow) in a follow-up radiograph, 85 days post-treatment. E: Resolution of the periapical lesion, new bone formation and remodeling of the apex, sealed by mineralized tissue, with thickening of the wall (arrow), are observed in an 8-year follow-up radiograph. 
another disadvantage for the use of a $\mathrm{CH}$ apical plug. However, Figures $1 \mathrm{~B}$ and $1 \mathrm{C}$ show that its radiopacity is similar to that of dentin, which allows visualizing the correct insertion of the material. It is possible that the easy application and low cost of $\mathrm{CH}$ could bring advantages over MTA. Moreover, if a failure occurs, treatment with a MTA apical plug is usually referred to apical surgery, whereas in cases where a $\mathrm{CH}$ apical plug is used, a non surgical approach is still possible.

Some might say that the present case is not relevant because $\mathrm{CH}$ has been extensively addressed in the literature. However, considering that its use as a long-term apical plug is not very common, it can be said that the present case is worth reporting. The outcome of this case shows that $\mathrm{CH}$ apical plug appears to be a valid option when treating teeth with overinstrumented apex, loss of the apical stop, extensive transportation and apical periodontitis.

\section{RESUMO}

Além do risco de extrusão periapical de material obturador pelo ápice, pode ser difícil conseguir um bom selamento apical em dentes com rizogênese incompleta ou alargamentos iatrogênicos da constrição apical. Casos assim representam um desafio durante a obturação do canal. Este caso clínico descreve a obturação de um canino superior direito com perda total da constrição apical por sobreinstrumentação, transporte excessivo e lesão periapical. Antes da obturação foi feito um tampão apical de hidróxido de cálcio com $5 \mathrm{~mm}$ de extensão. Para a realização do tampão, pontas de papel absorvente foram umedecidas em soro fisiológico, levadas ao pó do hidróxido de cálcio para absorvêlo e aplicadas várias vezes no ápice até se conseguir um tampão apical consistente. Em seguida o canal foi irrigado com solução salina para a remoção de eventuais resíduos de hidróxido de cálcio das suas paredes, secado com pontas de papel absorvente e obturado com um cone \#80 de guta percha invertido e cimento obturador à base de óxido de zinco e eugenol pela técnica da condensação lateral. O acompanhamento radiográfico de 8 anos mostrou selamento apical por tecido mineralizado, remodelação do ápice e reparo da lesão periapical.

\section{REFERENCES}

1. Mente J, Hage N, Pfefferle T, Koch MJ, Dreyhaupt J, Staehle HJ, Friedman S. Mineral Trioxide aggregate apical plugs in teeth with open apical foramina: a retrospective analysis of treatment outcome. J Endod 2009;35:1354-1358.

2. Giuliani V, Baccetti T, Pace R, Pagavino G. The use of MTA in teeth with necrotic pulps and open apices. Dent Traumatol 2002;18:217-221.
3. Mohammadi Z. Strategies to manage permanent non-vital teeth with open apices: a clinical update. Int Dent J 2011;61:25-30.

4. Felippe WT, Felippe MCS, Rocha MJC. The effect of mineral trioxide aggregate on the apexification and periapical healing of teeth with incomplete root formation. Int Endod J 2006;39:2-9.

5. Gu HJ, Xu Q, Liu LM, Ouyang Y. Treatment of chronic apical periodontitis teeth complicated by open apices with Vitapex in the adults. Shang Kou Qiang Yi Xue 2007;16:140-143.

6. Andreasen JO, Farik B, Munksgaard EC. Long-term calcium hydroxide as a root canal dressing may increase risk of root fracture. Dent Traumatol 2002;18:134-137.

7. Bogen G, Kuttler S. Mineral trioxide aggregate obturation: a review and case series. J Endod 2009;35:777-790.

8. Holland R, Ferreira LB, de Souza V, Otoboni-Filho JA, Murata SS, Dezan-Junior E. Influence of the type of vehicle and limit of obturation on apical and periapical tissue response in dogs' teeth after root canal filling with mineral trioxide aggregate. J Endod 2007;33:693-697.

9. Yildirim T, Gencoglu N. Use of mineral trioxide aggregate in the treatment of large periapical lesions: reports of three cases. Eur J Dent 2010;4:468-474.

10. D'Arcangelo C, D'Amario M. Use of MTA for orthograde obturation of non-vital teeth with open apices: report of two cases. Oral Surg Oral Med Oral Pathol Oral Radiol Endod 2007;104:98101.

11. Pace R, Giuliani V, Pini Prato L, Baccetti T, Pagavino G. Apical plug technique using mineral trioxide aggregate: results from a case series. Int Endod J 2007;40:478-484.

12. Erdem AP, Sepet E. Mineral trioxide aggregate for obturation of maxillary central incisors with necrotic pulp and open apices. Dent Traumatol 2008;24:e38-e41.

13. Nosrat A, Asgary S. Apexogenesis treatment with a new endodontic cement: a case report. J Endod 2010;36:912-914.

14. Souza RA. Importance of the diagnosis in the pulpotomy of immature permanent teeth. Braz Dent J 2007;18:244-247.

15. Wang S-H, Chung M-P, Su W-S, Cheng J-C, Shieh Y-S. Continued root formation after replantation and root canal treatment in an avulsed immature permanent tooth: a case report. Dent Traumatol 2010;26:182-185.

16. Leonardo MR, Hernadez MEFT, Silva LAB, Tanomaru-Filho M. Effect of a calcium hydroxide-based root canal dressing on periapical repair in dogs: a histological study. Oral Surg Oral Med Oral Pathol Pral Radiol Endod 2006;102:680-685.

17. Ingle JI. Root canal obturation. JADA 1956;53:47-55.

18. Nair PNR. On the causes of persistent apical periodontitis: a review. Int Endod J 2006;39:249-281.

19. Lin S, Platner O, Metzger Z, Tsesis I. Residual bacteria in root apices removed by a diagonal root-end resection: a histopathological evaluation. Int Endod J 2008;41:469-475.

20. Souza RA, Dantas JCP, Colombo S, Lago M, Pécora, JD. Apical limit of root canal filling and its relationship with success on endodontic treatment of a mandibular molar: 11-year follow-up. Oral Surg Oral Med Oral Pathol Oral Med Endod 2011;112:e48-e50. 